\title{
A Brief Analysis on the Typical Writing Styles of O. Henry
}

\author{
Lu Tong ${ }^{1, a}$ \\ ${ }^{1}$ FLD, The Century College of Beijing University of Posts and Telecommunications(CCBUPT), \\ Yanqing District, Beijing, China. \\ alutong789@126.com
}

Keywords: O. Henry; Writing Styles; Humorous Language; Surprising Endings; Tearful Smile

\begin{abstract}
O. Henry was a well-known American writer in the world literature history. His writing is vivid and he is good at using irony, paronomasia, metaphor, metonymy and exaggeration to make the story full of fun. He is a master of surprising endings, and he usually design story plots dramatically, and makes some unexpected changes at the end, which is quite out of readers' expectations. Another writing style of his novel is tearful smile, and it is the combination of comedy and tragedy. In a word, O. Henry's typical writing styles can be concluded as follows: humorous language, surprising endings, and tearful smile.
\end{abstract}

\section{Introduction}

O. Henry (William Sidney Porter) is called "the father of modern American short stories" and is known as "encyclopedia of American humor" in the realm of world literature. His novels have been published repeatedly in the world, and there are numerous readers. O. Henry created a total of 300 short stories. His famous novels, such as The Cop and the Anthem, The Furnished Room, The Gift of the Magi, and The Last Leaf, earned him a great reputation in the world. It is no doubts that O. Henry make a significant contribution to the world literature.

His fame had spread far and wide for his unique writing styles. His famous short stories are usually funny and interesting, and he is a master of using paronomasia, irony, metaphor, and other ways to create humorous stories. Readers enjoy his humorous languages very much. All of his novels were ingeniously conceived, with the O. Henry-style ending(surprising endings), which is often contrary to readers' expectations. O. Henry's typical writing styles are generally branded with such features as humorous language, surprising endings, and tearful smile.

\section{The Typical Writing Styles of O. Henry}

\subsection{The Humorous Language}

The languages in O. Henry's novels are rich and colorful, such as slang, irony, metaphor, metonymy, exaggeration, paronomasia and so on. Therefore, his stories are usually amusing and humorous.

In The Cop and the Anthem, humorous languages can be easily found. For example:

"Soapy walked past the policeman sadly. He seemed doomed to liberty." As we know, the phrase "be doomed to" is usually followed by negative words like failure, death, frustration, destruction, etc., while liberty is a positive word, meaning freedom and happiness. Therefore, it is very strange and funny to express "He seemed doomed to liberty.", because no one will consider liberty negative except the poor and homeless Soapy. However, the funny expression indicates the true thoughts of Soapy, because liberty means coldness, hunger, and death to him in the cold winter. So he wishes to be put into prison to spend the cold winter. O. Henry shows us poor Soapy's miserable life and abnormal belief in such strange and humorous languages.

"At a table he sat and consumed beefsteak, flapjacks, doughnuts, and pie." Generally speaking, consume is a formal word, meaning eating or drinking eagerly and in a large amount. Instead of the 
ordinary word eat, O. Henry uses the formal word consume to deseribe the miserable life of poor Soapy, and readers may laugh into tears while reading the humorous sentence.

"Up Broadway he turned, and halted at a glittering café, where are gathered together nightly the choicest products of the grape, the silkworm and the protoplasm." The rhetoric method used in the sentence is metonymy. We can infer that the grape refers to the wine, the silkworm refers to fancy clothes, and the protoplasm refers to the rich man. The use of metonymy makes these sentences much funny. The humous languages bring great enjoyment to readers.

In the story The Last Leaf, Johnsy, a poor painter, had come down with pneumonia, lying on her bed, hardly moving. She often looked out of the window and counted the leaves of ivy vine on the wall. She had lost confidence in fighting against pneumonia and thought that she would die when the last leaf of ivy vine on the wall falls. A doctor examined Johnsy and asked Sue, a friend of Johnsy, whether Johnsy had anything in her mind. "I will do all that science can do," said the doctor. "But whenever my patient begins to count the carriages at her funeral, I take away fifty percent from the curative power of medicines." In the opinion of the doctor, Johnsy should keep up her spirits and increases her self-confidence in overcoming the disease instead of planning her funeral. The author uses his unique humour language to tell readers that the Johnsy was hopeless about herself.

One day, Sue told her neighbor Old Behrman, an old artist, the story of Johnsy. The description of the old artist is full of humour too. "Old Behrman was a painter who lived on the ground floor of the apartment building. Behrman was a failure in art. For years, he had always been planning to paint a masterpiece, but had never yet begun it. He earned a little money by serving as a model to artists who could not pay for a professional model. He was a fierce, little, old man who protected the two young women in the studio apartment above him." "In one corner was a blank canvas on an easel that had been waiting there for twenty-five years to receive the first line of the masterpiece." Reading these humorous languages, readers may burst into laughter: he had planned to paint a masterpiece for twenty-five years! He didn't start his painting at all! Furthermore, readers can see an elderly artist frustrated by his inability to paint what is in his heart. "This is not any place in which one so good as Miss Johnsy shall lie sick," yelled Behrman, "Someday I will paint a masterpiece, and we shall all go away." It sounds funny to the readers, because Behrman had never painted a work of art. However, it was him who saves Johnsy's life at the end of the story. The last leaf Old Behrman painted on the wall not only saved Johnsy's life but also became his real masterpiece forever.

\subsection{Surprising Endings}

The most important feature of O. Henry's writing is the unexpected ending. The story usually begins in one direction and just when the reader thinks they can predict the ending, but finally it turns to a totally different direction. These surprising endings are always reasonable, even if the ending is sad.

In the begining of The Gift of the Magi, the author tell us how precious the watch and the hair to the poor young couple. In order to exchang christmas gifts, the poor young couple are not hesitate to sell the most precious possessions of each. As a result, however, their two precious gifts they bought all became useless at the end of the story, while they got the most precious thing than any material objects-love. It makes readers smile bitterly, and the more important is that we can feel the true unselfish love between the couple. This is the typical surprising ending of O. Henry's writing.

In The Furnished Room, the young man was looking for a girl for five months, "so much time spent by day in questioning managers, agents, schools and choruses; by night among the audiences of theatres from all-star casts down to music halls so low that he dreaded to find what he most hoped for." Readers can find that the young man was full of hope at that time, and tried his best to find the girl out. However, he found no trace. Readers may think that the man might find the girl in the end with his hard and careful search, and with his strong will. Just when readers thinks they can predict the ending, the story turns to a totally different direction. At the end of the story, there is the dialogue, from which the man learned that the girl comimted suicide in the same room a week ago. Obviously, 
the author give us a surprising ending that contrary to our expectations. At last, the man comminted suicide desperately with gas in the same room, which is also quite out of reader' expectations.

The Cop and the Anthem is a typical example of surprising endings. When winter was coming, the poor and homeless Soapy hoped to be arrested so that he could live in the warm prison in the cold winter. Therefore, what he needed to do was to commit crime on purpose, and wait to be arrested. Readers may surely think he would be arrested soon, but to readers' surprise, it was not an easy task at all! Soapy tried every effort to do various evil things, only to fail time and time again. At first, he planned to have a free meal in a café and refuse to pay the bill, and he thought the cop would certainly arrest him. Unfortunately, the water drove him away because the waiter saw his frayed trousers and decadent shoes. Later, he successfully came into a restaurant and had a big meal, yet he was just beaten by waiters instead of being sent to the police station. In the story, Soapy tried six times to commit crime and none of them succeed, which is a surprise to readers. However, the end is much more surprising. When Soapy heard an anthem from the church, he was much touched and decided to start with a new life. In the end, a policeman arrested him for his being idleness when he gave up his original idea and was planning his future! How ironic it is! The surprising ending exceeds everyone's expectation.

\subsection{The Tearful Smile}

Although some plots or ends of O. Henry's story are sad, there are uaually some hopes and warm and true feelings in the story, which will makes readers smile bitterly. This writing style is called tearful smile, and it another typical writing styles of O. Henry. In fact, Tearful smile is the combination of comedy and tragety.

The novel The Gift of the Magi shows fully the unique writing style of "tearful smile".

The couple in the story are very poor, and they only could afford the furnished flat at $\$ 8$ per week, and all the money they have is "one dollar and eighty-seven cents". The pennies are saved one and two at a time by bulldozing the grocer and the vegetable man and the butcher. So readers can see that the life of them is very very hard, and can be regarded as a tragedy to some extent. However, the poor couple still live in the atmosphere of comedy, because they understand each other and love each other very much. They always think about the other and just try their best to make each other happier. At the end of the story, when the gifts all became useless, they are much moved and more happy because they get the most precious love from each other. After reading the story, readers usually don't know whether they should smile or cry for the surprising end. Even though readers smile, maybe it is a tearful smile; after all, the precious watch and the beautiful hair were gone. If readers are moved into tears, their tears maybe the happy tears: the true love of the couple was not gone! In a word, readers will not respond easily to the writing style of tearful smile, which is the magic of this style.

The last leaf is another example of "tearful smile"writing style.

Johnsy had no faith to overcome the disease and though herself just like a weary leaf, and said "When the last leaf falls, I must go, too." When there was only a last leaf left on the wall, Johnsy was much scared and was close to death. After a stormy and cold night, "the last ivy leaf was still there". Therefore Johnsy regained confidence and her will to live revived. But at the end of the story,to everyone's surprise, Old Behrman died of pneumonia in the hospital. And it turned out that the last leaf "is Behrman's masterpiece - he painted it there the night that the last leaf fell." After Old Behrman learned the story of Johnsy, he decided to do something to save the young girl without anyone's noticing. So he created the masterpiece he had been struggling to paint on a stormy and cold night. Unfortunately, Old Behrman caught a cold and died quickly.

At first, readers may suppose that Johnsy would surely die from fear and despair; but to the readers' relief, she survived the serious pneumonia at last. Readers may feel satisfied with the good ending and be happy until there came a bad news: Old Behrman died of pneumonia. Then readers realize that Old Behrman save Johnsy at the cost of his own life. After finishing the story, readers feel 
moved by the selfless love and the true friendship among the poor artists, and their feelings may be a combination of happpiness and sadness, that is, a tearful smile.

\section{Conclusion}

O. Henry's novels is characterized by vivid features. First of all, it is his humorous languages. He is a master of using paronomasia, metaphor, irony and so on to make the story more interesting and funny. Secondly, O. Henry is skilled in conceiving the surprise but logical ending, which is known as the most famous feature of his writing. His stories are ingeniously conceived, and the result always changes suddenly and contrary to readers' expectations. The unexpected endings can make people think more about the problems or situations that the story has revealed. Thirdly, most of O. Henry's novels seemed to be a comedy but meanwhile we can feel the deep sorrow. It is the style of "tearful smile", which is is the combination of comedy and tragety. In O. Henry's stories, even though the ending is sad, there are usually some hopes and lights in it.

O. Henry created some new writing styles, and they are imitated by numerous writers at home and abroad. People appreciate both his writing skills and his extraordinary ideas. For a long time, scholars and readers think highly of O. Henry's stories and writing styles. It is no doubts that O. Henry make a significant contribution to the world literature.

\section{References}

[1] David Stuart: O. Henry: A Biography of William Sydney Porter. Chelsea: Scarborough Publishers(1990).

[2] Joel Porter: New Essays on O Henry. Beijing: Peking University Press(2007).

[3] John Kirkpatrick: The Short Stories of O. Henry. Beijing: Foreign Languages Teaching and Research Press(1987).

[4] Jonathan Freedman: The Themes of O. Henry . Shanghai: Shanghai Foreign Language Education Press (2000).

[5] O. Henry: The Selection Short Stories of O. Henry. Shanghai: World Publishing Corporation(2004).

[6] Rena Korb: An overview of The Gift of the Magi. Short Stories for Students. Detroit: Gale(2002).

[7] Fu Jingchuan: A History of 20th Century American Literature. Beijing: Foreign Language Teaching and Research Press(1998).

[8] Ma Jun: On O. Henry's Writing Style: Exemplified by "The Cop and the Anthem", Journal of Shenyang Normal University Social Sciences Edition(2005).

[9] Wen zhongying: Story plots and subject thoughts of O. Henry's short stories, Journal of Xinyang Agricultural College(2007).

[10] Wu Dingbo: An Outline of American Literature. Shanghai: Shanghai Foreign Language Education Press(1998).

[11] Wu Weiren: History and Anthology of American Literature. Beijing: Foreign Language Teaching and Research Press(1990).

[12] Zhao wenbo: Analyzing O. Henry's Writing Style in "The Cop and the Anthem", Journal of Jilin Teachers Institute of Engineering and Technology(2008). 